\title{
A retrospective of retractions: the striking record in 2011
}

\begin{abstract}
John Darsee was a young clinical investigator with a long list of publications in top-tier journals and a promising career ahead of him in cardiology research. Described by a former supervisor as "one of the most remarkable young men in American medicine," Darsee was offered a faculty position at the Harvard Medical School in Boston at the age of 33. But then his career quickly started to unravel. One day, colleagues caught Darsee fraudulently labeling data for a study into heart attacks; further investigations revealed scientific misconduct on a massive scale, and, eventually, Darsee was fired and barred from receiving federal grant money for ten years. More than $\mathbf{8 0}$ of his papers were withdrawn from the literature. He ultimately apologized for publishing "inaccuracies and falsehoods."

That was twenty years ago. But the problem of retractions has not gone away-in fact, it may be getting worse, with the number of such notices on the rise. And whereas the Darsee case took more than decade to come to light (and only then because of an accidental discovery), these days image detection software and the vigilance of media outlets such as Retraction Watch (see page 1539) can catch irregularities-be they due to innocent error or misconduct-much sooner. The ability to track these changes provides benefits to biomedicine, as experiments in the scientific literature lay the foundation for future experiments. Here we look back at instances from the past year where multiple papers from certain investigators came under scrutiny.
\end{abstract}

The case of Naoki Mori is illustrative of the controversies that can surround the images published in research papers. Since June 2010, the Japanese cancer immunologist has lost at least 30 papers to retractions for image manipulation or duplication, mostly involving studies related to strategies for blocking human T cell leukemia virus type 1 , a retrovirus responsible for causing leukemia and lymphoma. For his actions, Mori received a ten-year publishing ban from the American Society for Microbiology. Mori, who confirmed the ban, lost his job at the University of Ryukyus in Okinawa in August 2010. But, after going to court over the decision, Mori was reinstated to his post in June of this year. An investigation is still ongoing at Nagasaki University, Mori's employer from 1997 to 2002 , into research papers originating from his time there. "I acknowledge that we were lax in certain regards in the preparation of papers, but would like to stress that there was never an intention to manipulate the results or deceive in any way," Mori wrote in an email to Nature Medicine.

Image irregularities also seem to have cost a scientist his job in Canada, not to mention the standing of several published studies. In September-less than a month after the retractions of two papers in the Journal of Biological Chemistry that purported to link microRNAs to abnormal heart rhythms - the cardiology researcher Zhiguo Wang resigned from the University of Montreal, and the affiliated Montreal Heart Institute (MHI) subsequently shuttered his lab there. A few weeks later, Wang retracted another paper in the Journal of Cell Science, citing the "misuse and reuse" of images; he has since made public his intention to withdraw three more from the Journal of Cellular Physiology. According to an investigation conducted by MHI officials, however, Wang's 2007 Nature Medicine paper on the role of microRNA-1 does not need to be retracted (see Nat. Med. 13, 486-491, 2007, and 1693 in this issue). "I am taking the responsibility as the director of the laboratory, but I have never personally manipulated any images or fabricated data for any of our publications," Wang wrote in an email when contacted for this story.

Some retractions have ripple effects beyond the lab. In September, former participants who enrolled in clinical trials overseen by cancer geneticist Anil Potti (and members of the study subjects' families) sued Duke University, its administrators and physicians for allowing trials to go ahead based on data that they allegedly knew to be suspect. Potti resigned from the Durham, North Carolina institution effective December 2010 amidst allegations that he manipulated statistical analyses and padded his resume with fake credentials. Since then, Potti has moved to the Coastal Cancer Center in South Carolina, and seven of his papers, including a 2006 report in this journal (see Nat. Med. 17, 135, 2011), have been retracted. The data in question claimed to link gene-expression profiles in cancer cells with sensitivity to chemotherapy drugs. Potti did not respond to requests for comment.

Although not yet withdrawn from the scientific record, a large number of papers-including one published in Nature Medicine (13, 1375-1381, 2007)—by former National University of Singapore (NUS) scientist Alirio Melendez are now under scrutiny. Since March, NUS - in collaboration with the UK's University of Glasgow and University of Liverpool, Melendez's past and present employers, respectively — has been looking into around 70 papers for evidence of research misconduct. In July, figure irregularities felled a study published just five months earlier in Nature Immunology. And, in October, Science issued an 'expression of concern' about a June 2010 report from Melendez containing images that the journal had already corrected once since the paper came out that summer. Both papers demonstrated potential new therapies for septic shock. Melendez was suspended without prejudice from his position as chair of immunopharmacology at Liverpool in April, pending the outcome of the investigation. When contacted for this story, Melendez wrote that he is now on medical leave and that he "personally had nothing to do with the errors in the questioned papers."

But perhaps no one has had his name attached to more retraction notices than Joachim Boldt, the former chief anesthesiologist at the Clinical Center of Ludwigshafen in Germany. A year ago, the journal Anesthesia \& Analgesia retracted a paper of his. But that pales in comparison to the development in March, when the editors of 18 research journals issued a joint statement announcing plans to retract 88 papers dating back to 1999 . This action came in response to an investigation by the State Medical Association of Rheinland-Pfalz, which concluded in February that Boldt had conducted the majority of his published studies without institutional review board approval. Another investigation is currently ongoing at Ludwigshafen into whether Boldt, who was dismissed from the hospital late last year, also fabricated data for his studies, many of which claimed to show the safety of drugs known as colloids, which are used to boost blood volume in people undergoing surgery. The hospital's investigative committee says Boldt has admitted forging the signatures of the coauthors on a manuscript submission form. He did not respond to requests for comment for this piece. 